DOI: $10.19195 / 0524-4544.327 .9$

\author{
MAŁGORZATA OFIARSKA \\ ORCID: 0000-0001-5311-0201 \\ Uniwersytet Szczeciński \\ malgorzata.ofiarska@usz.edu.pl
}

\title{
Ewolucja pozycji prawnej kolegium regionalnej izby obrachunkowej
}

\begin{abstract}
Abstrakt: Regionalne izby obrachunkowe, ustanowione w 1992 roku i funkcjonujące od 1993 roku, są organami kontroli gospodarki finansowej gmin, związków międzygminnych, innych komunalnych osób prawnych i sejmików samorządowych oraz organami nadzoru nad działalnością komunalną w zakresie spraw budżetowych. W ciągu ostatnich 25 lat funkcjonowania zakres funkcji i zadań r.i.o. był stale poszerzany. Okoliczność ta znacząco wpłynęła na status prawny kolegium r.i.o., które jest jedynym organem r.i.o. kierowanym przez prezesa r.i.o. Status prawny kolegium r.i.o. określają wymagania adresowane do kandydatów przewidzianych do objęcia funkcji w kolegium, obowiązująca procedura konkursowa oraz fakt, że członkowie kolegium są powoływani przez Prezesa Rady Ministrów na wniosek prezesa r.i.o. Członkowie kolegium r.i.o. korzystają z ochrony prawnej jako funkcjonariusze publiczni w zakresie realizowanych zadań, przy czym są niezależni w zakresie funkcji nadzorczych i kontrolnych. Powyższe ustawowe przywileje powinny wpłynąć pozytywnie na praktykę sądową i konsultacyjną kolegiów r.i.o.
\end{abstract}

Słowa kluczowe: samorząd terytorialny, regionalna izba obrachunkowa, nadzór, sprawy budżetowe, opinie.

\section{Wprowadzenie}

Tradycje izb obrachunkowych działających na ziemiach polskich są stosunkowo długie. W literaturze przedmiotu w tym zakresie przywoływane są przykłady w postaci Głównej Izby Obrachunkowej Księstwa Warszawskiego utworzonej dnia 24 grudnia 1808 roku i działającej do 1813 roku oraz Izby Obrachunkowej Królestwa Polskiego utworzonej dnia 17 października 1816 roku i działającej do 1831 roku, a także Izby Najwyższej Obrachunkowej Królestwa Polskiego działającej w latach 1832-1867. Były to organy kontroli nad finansami publicznymi, 
których zakres zadań i sposób funkcjonowania wzorowano na rozwiązaniach stosowanych we Francji oraz Rosji ${ }^{1}$. W okresie II Rzeczypospolitej nie utworzono wyspecjalizowanych organów kontroli gospodarki finansowej samorządu terytorialnego. Funkcje władz nadzorczych tylko w odniesieniu do uchwał związków komunalnych w sprawach pobierania samoistnych podatków komunalnych z punktu widzenia ich legalności i celowości, a także uchwał w sprawie pobierania dodatków komunalnych do podatków państwowych (wymagały zatwierdzenia przez władze nadzorcze) powierzono:

- wydziałom powiatowym w stosunku do gmin wiejskich (w b. dzielnicy rosyjskiej także do gromad) i gmin miejskich, niewydzielonych z powiatowych związków komunalnych, z wyjątkiem gmin miejskich w b. dzielnicy pruskiej, małopolskich gmin miejskich liczących powyżej 15 tys. mieszkańców;

— wydziałom wojewódzkim w stosunku do gmin miejskich, wydzielonych z powiatowych związków komunalnych, gmin miejskich w b. dzielnicy pruskiej oraz małopolskich gmin miejskich (z wyjątkiem m.st. Warszawy i m. Gdyni) i w stosunku do powiatowych związków komunalnych;

- Ministrowi Spraw Wewnętrznych działającemu w porozumieniu z Ministrem Skarbu w stosunku do gminy m.st. Warszawy i gminy m. Gdyni oraz w stosunku do krajowych związków komunalnych ${ }^{2}$.

Współcześnie funkcjonujące polskie regionalne izby obrachunkowe (dalej: r.i.o.) w zakresie ogólnej koncepcji nawiązują do rozwiązań stosowanych we Francji oraz Niemczech ${ }^{3}$. We Francji funkcjonują regionalne izby obrachunkowe, natomiast w Niemczech są to komunalne organy kontroli obrachunkowej, w obu przypadkach są to organy kontroli zewnętrznej w stosunku do jednostek samorządu terytorialnego. Słusznie jednak przestrzegano polskiego ustawodawcę przed recypowaniem do polskiego porządku prawnego tych rozwiązań, przede wszystkim z uwagi na odmienność struktur administracyjnych tych państw ${ }^{4}$.

${ }^{1}$ B. Cybulski, Od Głównej Izby Obrachunkowej Księstwa Warszawskiego do regionalnych izb obrachunkowych, [w:] Samorząd - finanse - nadzór i kontrola. XX-lecie regionalnych izb obrachunkowych, red. R.P. Krawczyk, M. Stec, Warszawa 2013, s. 37-69; P.M. Pilarczyk, Kontrola państwowa w Polsce przedrozbiorowej, „Kontrola Państwowa” 2016, nr 2, s. 162-163; G. Kościelniak, Najwyższa Izba Kontroli - 90 lat tradycji naczelnego organu kontroli państwowej. Wspótczesny obraz i proponowane kierunki zmian, „Państwo i Społeczeństwo” 2009, nr 3, s. 158.

2 § 8 Rozporządzenia III Ministra Spraw Wewnętrznych z dnia 16 sierpnia 1924 r. celem wykonania ustawy z dnia 11 sierpnia 1923 r. o tymczasowem uregulowaniu finansów komunalnych (Dz.U. Nr 82, poz. 790).

3 Zob. np. N. Gajl, Izba Obrachunkowa i regionalne izby obrachunkowe we Francji, „Kontrola Państwowa" 1992, nr 3, s. 64-76; U.K. Zawadzka-Pąk, Regionalne izby obrachunkowe we Francji, „Finanse Komunalne” 2010, nr 11, s. 71-77; N. Gajl, Cour des Comptes, Izba Obrachunkowa i Izby Regionalne we Francji, ,Samorząd Terytorialny” 1992, nr 4, s. 51-61; M. Bouvier, Finanse lokalne we Francji, Warszawa 1999, s. 149-153.

${ }^{4}$ E. Ruśkowski, E. Tegler, Kontrola działalności finansowej gmin we Francji i w Niemczech - wnioski dla Polski, Białystok 1991, s. 89. 
W polskiej doktrynie prawa administracyjnego i prawa samorządu terytorialnego problematyka regionalnych izb obrachunkowych jest podejmowana stosunkowo często. Badane są zarówno aspekty działalności kontrolnej i nadzorczej r.i.o., jak i problemy związane z ich usytuowaniem w strukturach administracji publicznej $^{5}$. Przedmiotem zainteresowania jest również wewnętrzna struktura organizacyjna tych podmiotów oraz pozycja prawna kolegium r.i.o. i przewodniczącego tego organu 6 .

Celem tego opracowania jest analiza i ocena materiału normatywnego, orzecznictwa sądów i dorobku doktryny prawa administracyjnego, a także prawa finansów publicznych dotyczących statusu prawnego kolegium regionalnej izby obrachunkowego jako jej organu. W opracowaniu poddano weryfikacji hipotezę, że w wyniku kolejnych nowelizacji ustawy o r.i.o. rozszerzających zakres funkcji i zadań r.i.o. wzrosło znaczenie kolegium r.i.o., które od 1 lipca 2005 roku jest jedynym organem tego podmiotu (do 30 czerwca 2007 roku drugim organem r.i.o. była komisja orzekająca w sprawach o naruszenie dyscypliny finansów publicznych). Wzrost znaczenia kolegium r.i.o. nastąpił nie tylko w ramach wewnętrznej struktury organizacyjnej r.i.o., ale również w odniesieniu do podmiotów zewnętrznych z sektora samorządowego poddanych właściwości kontrolnej i nadzorczej tego organu. W opracowaniu zastosowano metodę dogmatycznoprawną jako metodę dominującą oraz uzupełniająco metodę empiryczno-analityczną (w szczególności w odniesieniu do dorobku orzeczniczego sądów).

\section{Ewolucja podmiotowego i przedmiotowego zakresu działania r.i.o.}

Regionalne izby obrachunkowe w Polsce utworzono z dniem 1 stycznia 1993 roku $^{7}$ jako wyspecjalizowane w sprawach finansowych organy kontroli go-

5 Np. A. Sylwestrzak, Regionalne izby obrachunkowe, [w:] Prawo-Administracja - Policja. Księga pamiątkowa Profesora Wincentego Bednarka, red. J. Dobkowski, Olsztyn 2006, s. 167205; A. Sylwestrzak, Regionalne izby obrachunkowe w III Rzeczypospolitej Polskiej, „Gdańskie Studia Prawnicze" 2002, nr 8, s. 81-104; K. Badurowicz, T. Drab, Status ustrojowy regionalnych izb obrachunkowych $i$ ich wptyw na procedurę budzetowa jednostek samorzadu terytorialnego, „Rocznik Samorządowy” 2016, t. 5, s. 9-21; R.P. Krawczyk, Funkcja kontrolna regionalnych izb obrachunkowych - aktualne dylematy, „Finanse Komunalne” 2013, nr 1-2, s. 63-79.

6 Np. T. Turek, Organy regionalnej izby obrachunkowej. Struktura organizacyjna, zadania i kompetencje, „Miscellanea Iuridica” 2002, t. 2, s. 136-144; T. Turek, Wewnętrzna struktura organizacyjna regionalnych izb obrachunkowych, „Gubernaculum et Administratio” 2004, nr 3, s. 149-156; T. Turek, Pozycja ustrojowa Prezesa Regionalnej Izby Obrachunkowej w strukturze organizacyjnej Izby, „Miscellanea Iuridica” 2007, t. 9, s. 144-154.

7 Ustawa z dnia 7 października 1992 r. o regionalnych izbach obrachunkowych (Dz.U. z 2016 r. poz. 561 ze zm.), dalej: ustawa o r.i.o. 
spodarki finansowej gmin, związków międzygminnych, innych komunalnych osób prawnych i sejmików samorządowych oraz organy nadzoru nad działalnością komunalną w zakresie spraw budżetowych. $Z$ uwagi na status prawny ri.o. i sposób finansowania ich działalności (są państwowymi jednostkami budżetowymi) oraz zakres kompetencji przyznanych przez ustawodawcę zaproponowano w piśmiennictwie, aby określić je jako podmioty stanowiące szczególnego rodzaju pomost między administracją rządową a samorządem terytorialnym ${ }^{8}$.

Przedmiotowy zakres działalności ri.i.o. ewoluował, a cechą charakterystyczną było stopniowe rozszerzanie zakresu ich kompetencji kontrolnych i nadzorczych. W okresie ponad 25 lat funkcjonowania r.i.o. można wyodrębnić ważne cezury, które zadecydowały o współczesnej roli ri.i.o. Pierwszą z nich należy wiązać z nowelizacją ustawy dokonaną z dniem 1 stycznia 1995 roku, w wyniku której do przedmiotowego zakresu działalności r.i.o. włączono kontrolę zamówień publicznych dokonywanych przez wyżej wymienione podmioty ${ }^{9}$. W ramach kolejnej nowelizacji ustawy, dokonanej z dniem 10 października 1997 roku $^{10}$, wprowadzono regulacje mające wyraźnie akcentować niezależność r.i.o. względem kontrolowanych i nadzorowanych podmiotów sektora samorządowego. W zmienionym art. 1 ustawy o r.i.o. określono, że r.i.o. są państwowymi organami nadzoru i kontroli w stosunku do gmin, związków międzygminnych, innych komunalnych osób prawnych i sejmików samorządowych. Rola i znaczenie ri.o. w tym okresie istotnie wzrosły, co wiązało się z wejściem w życie Konstytucji Rzeczypospolitej Polskiej z dnia 2 kwietnia 1997 roku $^{11}$. Ustawa konstytucyjna z dnia 17 października 1992 roku o wzajemnych stosunkach między władzą ustawodawczą i wykonawczą Rzeczypospolitej Polskiej oraz o samorządzie terytorialnym ${ }^{12}$ nie zawierała żadnych postanowień odnoszących się do r.i.o.

W art. 171 ust. 2 konstytucji RP jednoznacznie ustalono, że r.i.o. są organami nadzoru nad działalnością jednostek samorządu terytorialnego w zakresie spraw finansowych. W piśmiennictwie wyrażono pogląd, że cytowana norma konstytucyjna powinna być traktowana co najmniej jako domniemanie właściwości rzeczowej r.i.o. do każdego aktu podjętego w sprawie finansowej ${ }^{13}$. Zwracano rów-

${ }^{8}$ M. Kwiatkowska, Geneza i przesłanki powstania regionalnych izb obrachunkowych w Polsce, „Prace Naukowe Wałbrzyskiej Wyższej Szkoły Zarządzania i Przedsiębiorczości” 2013, nr 4, s. 47.

9 Art. 93 pkt 1 Ustawy z dnia 10 czerwca 1994 r. o zamówieniach publicznych (Dz.U. z 2002 r. Nr 72, poz. 664 ze zm.). Ustawa o zamówieniach publicznych obowiązywała do dnia 1 marca 2004 r. i została z dniem 2 marca 2004 r. zastąpiona Ustawą z dnia 29 stycznia 2004 r. Prawo zamówień publicznych (Dz.U. z 2018 r. poz. 1986 ze zm.).

10 Ustawa z dnia 20 sierpnia 1997 r. o zmianie ustaw o regionalnych izbach obrachunkowych, o samorządzie terytorialnym oraz o finansowaniu gmin (Dz.U. Nr 113, poz. 734 ze zm.).

11 Dz.U. Nr 78, poz. 483 ze zm.

12 Dz.U. Nr 84, poz. 426.

13 J. Wilk, O właściwości nadzorczej regionalnej izby obrachunkowej nad uchwałami organów jednostek samorząu terytorialnego $w$ sprawie podatków $i$ opłat lokalnych, „Nowe Zeszyty Samorządowe" 2012, nr 1, s. 1. 
nież uwagę, że nadzór nad sprawami finansowymi jest rodzajowo odmienny od ogólnego pojęcia nadzoru nad działalnością samorządu terytorialnego, ponieważ ingerowanie $\mathrm{w}$ sferę prowadzenia spraw finansowych jest wkraczaniem zarazem w sferę korzystania z praw majątkowych związanych z autonomią woli osoby prawa publicznego ${ }^{14}$.

W wyniku wdrożenia drugiego etapu reformy samorządowej w Polsce (wprowadzenie samorządu na stopniu powiatu i województwa) od dnia 1 stycznia 1999 roku rozszerzono — w aspekcie podmiotowym — zakres kompetencji nadzorczej i kontrolnej r.i.o. Katalog podmiotów objętych nadzorem i kontrolą ze strony r.i.o. ukształtowano w sposób następujący: jednostki samorządu terytorialnego, związki międzygminne, stowarzyszenia gmin oraz stowarzyszenia gmin i powiatów, związki powiatów, stowarzyszenia powiatów, samorządowe jednostki organizacyjne mające osobowość prawną (w tym samorządowe osoby prawne), inne podmioty w zakresie wykorzystywania przez nie dotacji przyznawanych z budżetów jednostek samorządu terytorialnego ${ }^{15}$. Od dnia 1 stycznia 2016 roku do tego katalogu dodano związki powiatowo-gminne ${ }^{16}$ oraz związki metropolitalne ${ }^{17}$.

Określonej ewolucji podlegały również pozostałe funkcje r.i.o., których realizacja nie jest związana ze stosowaniem żadnych uprawnień o charakterze władczym lub ingerencyjnym. Od dnia 1 stycznia 1993 roku do dnia 9 października 1997 roku r.i.o., oprócz funkcji kontrolnej i nadzorczej, prowadziły działalność informacyjną i szkoleniową wyłącznie w zakresie spraw budżetowych. W wyniku nowelizacji ustawy o r.i.o. dokonanej z dniem 10 października 1997 roku, r.i.o. uprawniono do wydawania opinii w sprawach określonych ustawami oraz rozszerzono możliwość prowadzenia działalności informacyjnej i szkoleniowej w zakresie wszystkich spraw objętych nadzorem i kontrolą r.i.o. Kolejnej istotnej zmiany w zakresie niewładczej działalności r.i.o. dokonano z dniem 29 listopada 2003 roku, uprawniając te podmioty do opracowywania raportów i analiz ${ }^{18}$. Od dnia 1 stycznia 2005 roku r.i.o. zostały uprawnione do prowadzenia także działalności instruktażowej (oprócz już prowadzonej działalności informacyjnej i szkoleniowej). Od tego momentu działalność informacyjna i szkoleniowa może być prowadzona odpłatnie ${ }^{19}$, a uzyskane z tego tytułu wpływy stanowią dochody

14 T. Dębowska-Romanowska, O pojęciu ,, spraw finansowych" w rozumieniu art. 171 ust. 2 Konstytucji, „Gdańskie Studia Prawnicze” 2007, nr 1, s. 47.

15 Ustawa z dnia 18 grudnia 1998 r. o zmianie ustawy o regionalnych izbach obrachunkowych (Dz.U. Nr 160, poz. 1062).

16 Ustawa z dnia 25 czerwca 2015 r. o zmianie ustawy o samorządzie gminnym oraz niektórych innych ustaw (Dz.U. z 2015 r. poz. 1045).

17 Art. 57 Ustawy z dnia 9 października 2015 r. o związkach metropolitalnych (Dz.U. z 2015 r. poz. 1890 ze zm.).

18 Ustawa z dnia 24 lipca 2003 r. o zmianie ustawy o regionalnych izbach obrachunkowych, ustawy o kształtowaniu wynagrodzeń w państwowej sferze budżetowej oraz o zmianie niektórych ustaw (Dz.U. Nr 149, poz. 1454).

19 Ustawa z dnia 25 listopada 2004 r. o zmianie ustawy o finansach publicznych oraz o zmianie niektórych ustaw (Dz.U. Nr 273, poz. 2703 ze zm.). 
budżetu państwa. Przeznaczenie dochodów uzyskanych z tego tytułu jest efektem przyjętego statusu organizacyjno-prawnego r.i.o., które od momentu utworzenia są państwowymi jednostkami budżetowymi. Zgodnie z art. 11 ust. 1 Ustawy z dnia 27 sierpnia 2009 roku o finansach publicznych ${ }^{20}$ państwowe jednostki budżetowe pokrywają swoje wydatki bezpośrednio z budżetu państwa, a pobrane dochody odprowadzają na rachunek budżetu państwa.

\section{Kolegium r.i.o. - wybrane aspekty ustrojowoprawne}

W okresie od dnia 1 stycznia 1993 do dnia 30 czerwca 2005 roku w ri.o. funkcjonowały dwa organy, tzn. kolegium r.i.o. oraz komisja orzekająca w sprawach o naruszenie dyscypliny finansów publicznych. Zniesienie drugiego z ww. organów r.i.o. wiązało się z wejściem w życie Ustawy z dnia 17 grudnia 2004 roku o odpowiedzialności za naruszenie dyscypliny finansów publicznych ${ }^{21}$. Związane to było $\mathrm{z}$ istotną zmianą zasad powoływania i odwoływania członków komisji orzekających w sprawach o naruszenie dyscypliny finansów publicznych w celu zapewnienia ich niezależności i niezawisłości. Członkowie komisji orzekających dotychczas byli powoływani i odwoływani przez organy, przy których komisje zostały utworzone (m.in. prezesów r.i.o.). W okresie, w którym komisja orzekająca w sprawach o naruszenie dyscypliny finansów publicznych była organem r.i.o., jej przewodniczącym z mocy ustawy był zastępca prezesa r.i.o.. Takie rozwiązanie pozostawało w opozycji do niezależności i niezawisłości członków komisji orzekających $^{22}$. W związku z tym aktualnie funkcjonujące regionalne komisje orzekające w sprawach o naruszenie dyscypliny finansów publicznych są usytuowane przy r.i.o., a nie wewnątrz ich struktury organizacyjnej.

Skład kolegium r.i.o. oraz procedurę powoływania jego członków określa art. 15 ustawy o r.i.o. Stosowane w tym zakresie rozwiązania zmieniały się w okresie obowiązywania tej ustawy. Od momentu wejścia w życie ustawy o r.i.o. strona samorządowa posiada określone uprawnienia do kształtowania części składu kolegium r.i.o., z tym że ewoluowały rozwiązania szczegółowe stanowiące treść tej reguły. Do 31 grudnia 1998 roku funkcjonujące w tym okresie sejmiki wojewódzkie powoływały połowę członków kolegium ri.i.o., natomiast pozostałych członków powoływał Prezes Rady Ministrów. Kompetencja strony samorządowej w tym zakresie została istotnie ograniczona (po likwidacji sejmików wojewódzkich) od

20 Dz.U. z 2017 r. poz. 2077 ze zm.

21 Dz.U. z 2018 r. poz. 1458 ze zm.

22 Uzasadnienie projektu ustawy z dnia 17 grudnia 2004 r. o odpowiedzialności za naruszenie dyscypliny finansów publicznych — druk nr 1958 Sejmu RP IV kadencji. 
dnia 1 stycznia 1999 roku, ponieważ organy stanowiące j.s.t. tylko uprawniono do zgłaszania do kolegium r.i.o. kandydatów na członków tego kolegium. Po ich zaopiniowaniu przez kolegium r.i.o. powoływani są oni w skład kolegium przez Prezesa Rady Ministrów.

Od dnia 10 października 1997 roku wprowadzono regułę, według której członkostwo w kolegium r.i.o. ma charakter etatowy lub pozaetatowy. W pierwszym okresie obowiązywania tej reguły charakter członkostwa określał organ powołujący członka kolegium po zasięgnięciu opinii prezesa r.i.o. Od dnia 29 listopada 2003 roku dokonano w tym zakresie zmiany, której efektem było wzmocnienie pozycji prezesa r.i.o. W miejsce dotychczasowej opinii prezesa r.i.o., która nie miała charakteru opinii wiążącej organ powołujący członków kolegium ri.i.o., wprowadzono rozwiązanie polegające na składaniu przez prezesa r.i.o. wniosku do Prezesa Rady Ministrów w sprawie charakteru członkostwa w kolegium r.i.o. Ponadto wprowadzono rozwiązania zmierzające do wzmocnienia pozycji członków kolegium r.i.o. W wyniku tej nowelizacji etatowego członka kolegium powołuje się na czas nieokreślony, natomiast pozaetatowego członka kolegium powołuje się na sześcioletnią kadencję.

Ustabilizowaniu pozycji prawnej członka kolegium r.i.o. służyły również inne zmiany dokonywane $w$ art. 15 ustawy o r.i.o. $Z$ jednej strony ustawodawca w kolejnych okresach obowiązywania ustawy precyzował warunki formalne, które powinien spełniać członek kolegium r.i.o., natomiast z drugiej określał przesłanki dopuszczające odwołanie ze składu kolegium. Początkowo warunki formalne, jakie powinien spełniać członek kolegium r.i.o. określono bardzo ogólnie, stanowiąc, że powinien on „wykazywać się odpowiednimi kwalifikacjami zawodowymi i cieszyć się nienaganną opinią". Zastosowanie zwrotów niedookreślonych dawało dużą swobodę organom powołującym członków kolegium r.i.o. ${ }^{23}$. Nowelizacja ustawy o r.i.o. dokonana z dniem 1 stycznia 1999 roku wiązała się m.in. z wprowadzeniem zamkniętego katalogu warunków formalnych, jakie powinien spełniać członek kolegium r.i.o. (posiadanie pełnej zdolności do czynności prawnych; posiadanie obywatelstwa polskiego i korzystanie z pełni praw publicznych; ukończenie studiów wyższych administracyjnych, ekonomicznych lub prawniczych; posiadanie czteroletniego stażu pracy w jednostkach związanych z funkcjonowaniem samorządu terytorialnego lub finansów publicznych; brak skazania prawomocnym wyrokiem za przestępstwo popełnione $\mathrm{z}$ winy umyślnej). $\mathrm{Z}$ dniem 29 listopada 2003 roku uściślono jeden z warunków formalnych dotyczący poziomu wykształcenia członka kolegium r.i.o. stanowiąc, że powinien on „ukończyć magisterskie wyższe studia prawnicze, administracyjne, ekonomiczne lub posiadać stopień naukowy w jednej z tych dziedzin wiedzy".

23 M. Skąpski, M. Swora, Prawne problemy organizacji regionalnych izb obrachunkowych, „Ruch Prawniczy, Ekonomiczny i Socjologiczny” 2004, nr 2, s. 100. 
Skatalogowanie w ustawie o r.i.o. przesłanek uzasadniających odwołanie członka kolegium r.i.o. z jego składu nastąpiło z dniem 1 stycznia 1999 roku. We wcześniejszym okresie obowiązywania ustawy o r.i.o. stanowiono ogólnie o możliwości odwołania członków kolegium r.i.o. odpowiednio przez Prezesa Rady Ministrów lub sejmik wojewódzki, natomiast od dnia 10 października 1997 roku dodano w tym zakresie obowiązek uprzedniego zasięgnięcia opinii kolegium ri.o. Przesłanki uzasadniające odwołanie członka kolegium r.i.o. tworzą katalog zamknięty, ale zaistnienie co najmniej jednej z nich stanowi samodzielną podstawę uzasadniającą odwołanie członka kolegium r.i.o. ze składu tego organu. Katalog przesłanek ustawowych podlegał tylko zmianom redakcyjnym, natomiast ich istota została zachowana zgodnie z wersją pierwotną. Odwołanie członka kolegium r.i.o. następuje w przypadku: złożenia rezygnacji ze stanowiska; utraty co najmniej jednego z warunków niezbędnych do powołania w skład kolegium r.i.o.; stwierdzenia powtarzającego się naruszania prawa podczas wykonywania obowiązków lub uchylania się od ich wykonania. Ostatnia z ww. przesłanek odwołania, w przeciwieństwie do pozostałych, nie ma w pełni obiektywnego charakteru. Ustalenie jej wystąpienia w konkretnym przypadku w znacznym stopniu zależy od osobistej oceny prezesa izby jako podmiotu uprawnionego do zgłoszenia wniosku o odwołanie członka kolegium r.i.o. Przede wszystkim jednak w określeniu tej przesłanki odwołania brak jest bliższych cech, które wskazywałyby, jakiego rodzaju naruszenia prawa podczas wykonywania obowiązków członka kolegium ri.i.o. mogą uzasadniać odwołanie go z zajmowanego stanowiska. Nie zawiera ona również przykładowego podania okoliczności świadczących o uchylaniu się członka kolegium r.i.o. od wykonywania obowiązków, które uzasadniałyby jego odwołanie ${ }^{24}$.

O statusie kolegium r.i.o. decydują również ustawowe zakazy sformułowane w art. 23 ustawy o r.i.o., które są adresowane do wszystkich jego członków. Ograniczenia prowadzenia działalności gospodarczej przez pracowników r.i.o. zajmujących stanowiska prezesa oraz członka kolegium określają przepisy o ograniczeniu prowadzenia działalności gospodarczej przez osoby pełniące funkcje publiczne ${ }^{25}$. Prezes r.i.o., jego zastępca i pozostali członkowie kolegium r.i.o. nie mogą być członkami organów j.s.t. i samorządowych kolegiów odwoławczych ani być w stosunku pracy w: j.s.t., związkach j.s.t., związkach metropolitalnych, stowarzyszeniach j.s.t., samorządowych jednostkach organizacyjnych oraz innych podmiotach wykorzystujących dotacje przyznawane z budżetów j.s.t. Ponadto prezesowi r.i.o., jego zastępcy i pozostałym członkom kolegium r.i.o. nie można powierzyć wykonywania pracy na rzecz ww. jednostek na podstawie umowy cywilnoprawnej. Wprowadzone zakazy powinny stanowić gwarancję działań obiektywnych kolegium r.i.o. wobec podmiotów kontrolowanych i nadzorowanych.

24 Wyrok NSA z dnia 8 listopada 2016 r., I OSK 1864/15, Legalis nr 1639859.

25 Ustawa z dnia 21 sierpnia 1997 r. o ograniczeniu prowadzenia działalności gospodarczej przez osoby pełniące funkcje publiczne (Dz.U. z 2017 r. poz. 1393 ze zm.). 


\section{Prezes r.i.o. — wybrane aspekty ustrojowoprawne}

W okresie ponad 25 lat obowiązywania ustawy o r.i.o. ewoluowały również uregulowania prawne dotyczące pozycji prezesa r.i.o. Zasadą niezmiennie obowiązującą od momentu wejścia w życie przepisów ustawy o r.i.o. jest relacja między prezesem a kolegium r.i.o. Zgodnie z art. 15 ust. 1 ustawy o r.i.o. przewodniczącym kolegium r.i.o. jest prezes r.i.o. Pozycję prawną prezesa r.i.o. kształtują przede wszystkim postanowienia art. 16 ustawy o r.i.o. Jest on powoływany i odwoływany przez Prezesa Rady Ministrów, ale w różnych okresach w ramach tej procedury stosowano odmienne rozwiązania szczegółowe. W okresie od 1 stycznia 1993 do 31 grudnia 1998 roku powołanie i odwołanie prezesa r.i.o. następowało po zasięgnięciu opinii właściwego sejmiku wojewódzkiego. Od 1 stycznia 1999 do 28 listopada 2003 roku w miejsce opinii sejmików wojewódzkich wprowadzono obowiązek zasięgania opinii kolegium r.i.o. W żadnym z tych przypadków opinia nie miała charakteru wiążącego, a Prezes Rady Ministrów posiadał swobodę w zakresie obsadzenia tego stanowiska. Opinia stanowiła formę konsultacji między organem ustawowo umocowanym do powołania prezesa r.i.o. a organem r.i.o., którego pracami prezes miał kierować ${ }^{26}$.

Istotne zmiany procedury powoływania prezesa r.i.o. nastąpiły od dnia 29 listopada 2003 roku, polegały one przede wszystkim na wprowadzeniu kadencyjności tej funkcji (powołanie na okres 6 lat) i zasady wyłaniania kandydata na prezesa r.i.o. w drodze konkursu (pozostali członkowie kolegium r.i.o. również od tego momentu są wyłaniani w drodze konkursu). Stanowiło to efekt koncepcji zmierzającej do rozszerzenia kręgu podmiotów, które mogą pełnić funkcję prezesa r.i.o. ${ }^{27}$ Ogólne warunki przeprowadzania konkursu określono w art. 16 ustawy o r.i.o. ${ }^{28}$ Istotną rolę w tym zakresie powierzono kolegium r.i.o., które ogłasza w dzienniku o zasięgu ogólnokrajowym konkurs na stanowisko prezesa r.i.o., w terminie 60 dni przed upływem kadencji. W skład komisji konkursowej wchodzi trzech członków kolegium wybranych przez kolegium r.i.o. zwykłą większością głosów w obecności co najmniej połowy jego składu. Członkiem komisji konkursowej nie może być członek kolegium r.i.o., który kandyduje na stanowisko prezesa r.i.o.,

26 K. Sawicka, Pozycja ustrojowa regionalnych izb obrachunkowych w Polsce, [w:] Regulacje prawno-podatkowe i rozwiązania finansowe. Księga jubileuszowa Profesora Jana Gtuchowskiego, Toruń 2002, s. 247.

27 Uzasadnienie projektu ustawy z dnia 24 lipca 2003 r. o zmianie ustawy o regionalnych izbach obrachunkowych, ustawy o kształtowaniu wynagrodzeń w państwowej sferze budżetowej oraz o zmianie niektórych ustaw — druk nr 1097 Sejmu RP IV kadencji.

28 Szczegółowe warunki przeprowadzania konkursu określa Rozporządzenie Ministra Spraw Wewnętrznych i Administracji z dnia 19 stycznia 2004 r. w sprawie szczegółowych warunków przeprowadzania konkursu na prezesa regionalnej izby obrachunkowej (Dz.U. Nr 10, poz. 93), w tym: zadania komisji konkursowej; wzór ogłoszenia o konkursie; terminy zgłaszania kandydatów; etapy postępowania konkursowego; tryb postępowania odwoławczego. 
jest małżonkiem kandydata albo osobą pozostającą z nim we wspólnym pożyciu, jego krewnym albo powinowatym do drugiego stopnia bądź jest z nim związany z tytułu przysposobienia, opieki albo kurateli.

Przewodniczący komisji konkursowej w terminie 7 dni przedstawia kolegium r.i.o. listę kandydatów lub kandydata na prezesa r.i.o. Kolegium r.i.o. wybiera kandydata na prezesa r.i.o. w głosowaniu tajnym, bezwzględną większością głosów, w obecności co najmniej połowy jej składu, a następnie przewodniczący kolegium r.i.o. przesyła uchwałę ministrowi właściwemu do spraw administracji publicznej. Prezesa r.i.o. powołuje, po przeprowadzeniu konkursu, Prezes Rady Ministrów na wniosek ministra właściwego do spraw administracji publicznej. Po upływie kadencji dotychczasowy prezes r.i.o. pełni swoje obowiązki do czasu powołania nowego prezesa r.i.o.

W dorobku orzeczniczym sądów administracyjnych przyjmuje się szerokie rozumienie pojęcia „konkurs”, zastosowanego w treści art. 15a ustawy o r.i.o., obejmując nim także uchwałę zawierającą opinię kandydata na stanowisko członka kolegium r.i.o. Konkurs ten obejmuje nie tylko postępowanie konkursowe prowadzone przez komisję konkursową, ale także postępowanie prowadzone przez kolegium r.i.o., tzn. etap wyłonienia kandydatów przez komisję konkursową oraz etap opiniowania kandydatów przez kolegium r.i.o. ${ }^{29}$ Uchwała kolegium r.i.o. organu administracji publicznej - o negatywnym zaopiniowaniu kandydata na stanowisko członka kolegium r.i.o. w celu przedstawienia jego kandydatury Prezesowi Rady Ministrów nie pozostaje bez wpływu na sytuację osoby zainteresowanej, która w odpowiedzi na ogłoszenie konkursu wzięła w nim udział. Uchwała taka ma charakter władczych czynności publicznoprawnych, których adresatem są uczestnicy konkursu realizujący swoje własne uprawnienia do udziału w konkursie. W świetle orzecznictwa sądów administracyjnych postępowanie konkursowe jest postępowaniem z zakresu administracji publicznej ${ }^{30}$.

$\mathrm{Z}$ dniem 29 listopada 2003 roku dodano przepis art. 16a ustawy o r.i.o. regulujący procedurę odwołania prezesa ri.i.o. Odwołanie prezesa r.i.o. może nastąpić tylko w przypadkach określonych w art. 15 ust. 9 tej ustawy, tzn. złożenia rezygnacji ze stanowiska; utraty co najmniej jednego $\mathrm{z}$ warunków formalnych niezbędnych do pełnienia tej funkcji; stwierdzenia powtarzającego się naruszania prawa podczas wykonywania obowiązków lub uchylania się od ich wykonania. Prezesa r.i.o. odwołuje Prezes Rady Ministrów na wniosek ministra właściwego do spraw administracji publicznej. Decyzję o odwołaniu, wraz z uzasadnieniem, doręcza się zainteresowanemu. Na decyzję o odwołaniu zainteresowanemu służy prawo wniesienia skargi do sądu administracyjnego w terminie 14 dni od dnia jej doręczenia. Wniesienie skargi wstrzymuje odwołanie ze stanowiska. Sąd administracyjny wyznacza rozprawę $w$ tej sprawie w terminie przypadającym w ciągu 30 dni od

29 Wyrok WSA w Łodzi z dnia 28 lutego 2014 r., III SA/Łd 1261/13, Legalis nr 976976.

30 Wyrok WSA w Łodzi z dnia 22 maja 2013 r., III SA/Łd 413/13, Legalis nr 788613. 
dnia złożenia skargi. Nadzór nad działalnością r.i.o. sprawowany przez ministra właściwego do spraw administracji publicznej, jak również wpływ Prezesa Rady Ministrów na skład personalny kolegium ri.o. nie przesądzają o podległości organizacyjnej i funkcjonalnej tego organu w relacji do administracji rządowej ${ }^{31}$.

Po upływie kadencji prezesa r.i.o. albo po jego odwołaniu w związku ze złożoną rezygnacją pozostaje on etatowym członkiem kolegium r.i.o. Jeżeli przekształcenie stosunku pracy prezesa kolegium r.i.o. powodowałoby przekroczenie liczby członków tego kolegium ${ }^{32}$ albo wynikających z budżetu państwa limitów zatrudnienia i kwot wynagrodzeń dla danej grupy osób objętych mnożnikowym systemem wynagrodzenia, liczby te zwiększa się o jeden, a uzupełnienie środków na wynagrodzenia następuje z rezerwy budżetu państwa przeznaczonej na sfinansowanie nieprzewidzianych zmian organizacyjnych.

Istotne są również postanowienia ustawy o r.i.o. kształtujące status prawny zastępcy prezesa r.i.o. Od momentu wejścia w życie przepisów ustawy o r.i.o. obowiązuje reguła, według której spośród członków kolegium r.i.o. zastępcę prezesa r.i.o. powołuje i odwołuje Prezes Rady Ministrów na wniosek prezesa r.i.o., a więc kandydat na stanowisko zastępcy prezesa r.i.o. musi być członkiem kolegium ri.o w momencie zgłaszania jego osoby do pełnienia tej funkcji.

Ustawodawca traktuje kolegium r.i.o. w szczególnych przypadkach jako pewną jednolitą wewnętrznie strukturę, pomimo wyodrębnienia w przepisach ustawy o r.i.o. funkcji i zadań wprost przypisanych prezesowi r.i.o. oraz jego zastępcy. Przykładem tego szczególnego traktowania kolegium r.i.o. są postanowienia art. 2 ustawy o r.i.o., zgodnie z którym nadzór nad działalnością ri.o. sprawuje minister właściwy do spraw administracji publicznej na podstawie kryterium zgodności z prawem. W razie powtarzającego się naruszania prawa przez r.i.o., Prezes Rady Ministrów na wniosek ministra właściwego do spraw administracji publicznej może rozwiązać kolegium r.i.o., określając jednocześnie termin powołania kolegium r.i.o. w nowym składzie nie dłuższy niż 3 miesiące. Rozwiązanie kolegium jest równoznaczne z odwołaniem prezesa i zastępcy prezesa r.i.o. W takiej sytuacji Prezes Rady Ministrów wyznacza, na wniosek ministra właściwego do spraw administracji publicznej, tymczasowego prezesa r.i.o., który do czasu utworzenia kolegium r.i.o. w nowym składzie pełni funkcję tego organu. $\mathrm{Z}$ treści przepisu art. 2 ust. 3 ustawy o r.i.o. wynika, że tymczasowy prezes nie jest organem r.i.o., a jedynie pełni funkcję organu, jakim jest kolegium r.i.o.

31 T. Turek, Regionalna izba obrachunkowa jako organ kontroli nad działalnościa jednostek samorzadu terytorialnego w zakresie gospodarki finansowej, [w:] System finansów samorządu terytorialnego. Wybrane problemy, red. L. Patrzałek, Poznań-Wrocław 2003, s. 216.

32 Określonej w rozporządzeniu Prezesa Rady Ministrów wydanego na podstawie delegacji sformułowanej w art. 2 ust. 4 ustawy o r.i.o. Aktualnie w tym zakresie obowiązuje Rozporządzenie Prezesa Rady Ministrów z dnia 16 lipca 2004 r. w sprawie siedzib i zasięgu terytorialnego regionalnych izb obrachunkowych oraz szczegółowej organizacji izb, liczby członków kolegium i trybu postępowania (Dz.U. Nr 167, poz. 1747). 
Zadania prezesa r.i.o. określono w art. 17 ustawy o r.i.o. W wyniku kilku nowelizacji tego przepisu rozszerzono i uszczegółowiono pierwotnie ogólnie sformułowane zadania prezesa r.i.o., które wcześniej sprowadzały się przede wszystkim do reprezentowania ri.o. na zewnątrz, kierowania obradami kolegium ri.o. oraz wyznaczania składów orzekających. Należy zwrócić uwagę przede wszystkim na zadania prezesa r.i.o. wynikające z relacji zachodzących między nim oraz kolegium r.i.o. W tym kontekście należy wymienić następujące kompetencje prezesa r.i.o.: przedkładanie, po przyjęciu przez kolegium r.i.o., ministrowi właściwemu do spraw administracji publicznej rocznych sprawozdań z wykonania budżetu oraz sprawozdań z działalności kontrolnej i informacyjno-szkoleniowej r.i.o. w terminie do końca pierwszego kwartału roku następującego po roku objętym sprawozdaniem; występowanie do Prezesa Rady Ministrów z wnioskami o powołanie i o odwołanie zastępcy prezesa oraz o powołanie, odwołanie lub zmianę charakteru zatrudnienia członka kolegium r.i.o.; występowanie do Prezesa Rady Ministrów o zwiększenie liczby członków kolegium r.i.o.; wyznaczanie składów orzekających i ich przewodniczących; ogłaszanie konkursów na stanowisko członka kolegium r.i.o.; zwoływanie posiedzeń kolegium r.i.o.; powoływanie, spośród członków kolegium r.i.o., komisji do rozpatrywania spraw dotyczących powiadomień przez skarbnika (głównego księgowego budżetu j.s.t.) o przypadkach dokonania kontrasygnaty na pisemne polecenie zwierzchnika oraz wyznaczanie przewodniczącego tej komisji.

\section{Forma prawna działania kolegium r.i.o.}

Kolegium r.i.o. jest wieloosobowym (kolegialnym) organem r.i.o. i w związ$\mathrm{ku} \mathrm{z}$ tym prawną formą jego działania jest uchwała. Niniejsza forma związana jest z zadaniami wykonywanymi przez ten organ w zakresie kontroli, nadzoru, wydawania opinii, przedstawiania raportów, a także w sprawach organizacyjnych dotyczących r.i.o. W art. 18 ust. 1 ustawy o r.i.o. wymieniono rodzaje spraw, których rozstrzygnięcie możliwe jest wyłącznie przez pełny skład kolegium r.i.o. Katalog tych spraw systematycznie jest rozszerzany od dnia 10 października 1997 roku, tzn. od momentu pierwszej nowelizacji tego przepisu ustawy. Pierwotnie ustawodawca wskazywał sześć rodzajów spraw, natomiast aktualnie katalog obejmuje dziesięć rodzajów spraw. Jego cechą charakterystyczną jest „otwarty charakter” na gruncie ustawy o r.i.o., ponieważ ostatnią pozycją tego katalogu są „uchwały podejmowane w innych sprawach, określonych w odrębnych przepisach". Pozostałe sprawy zastrzeżone do wyłącznej kompetencji pełnego składu kolegium r.i.o. są następujące:

- ustalanie budżetu j.s.t. oraz orzekanie o nieważności uchwał i zarządzeń organów j.s.t. (dotyczących procedury uchwalania budżetu i jego zmian, budżetu 
i jego zmian, zaciągania zobowiązań wpływających na wysokość długu publicznego j.s.t. oraz udzielania pożyczek, zasad i zakresu przyznawania dotacji z budżetu j.s.t., podatków i opłat lokalnych, absolutorium, wieloletniej prognozy finansowej i jej zmian);

— rozpatrywanie odwołań od wydanych opinii o przedkładanych: projektach uchwał budżetowych j.s.t., informacjach organów wykonawczych j.s.t. o przebiegu wykonania budżetu za pierwsze półrocze, sprawozdaniach z wykonania budżetu wraz z informacjami o stanie mienia j.s.t. i objaśnieniami;

— przyjmowanie sprawozdań z działalności kontrolnej i informacyjno-szkoleniowej r.i.o.;

- uchwalanie wniosków do projektu budżetu r.i.o. oraz ramowego planu pracy;

— przyjmowanie sprawozdań z wykonania budżetu r.i.o. oraz rocznego ramowego planu pracy r.i.o., w tym planu kontroli;

- rozpatrywanie zastrzeżeń do wniosków zawartych w wystąpieniach pokontrolnych;

— opiniowanie kandydatów na członków kolegium;

— wybór kandydata na prezesa r.i.o.;

- uchwalanie regulaminu organizacyjnego r.i.o.

Zgodnie z art. 18a ust. 3 ustawy o r.i.o. rozstrzygnięcia nadzorcze, postanowienia $\mathrm{i}$ opinie kolegium r.i.o. w sprawach objętych ustawą są podejmowane w formie uchwał, natomiast według art. 18 ust. 2 i 3 tej ustawy do podjęcia uchwały niezbędna jest bezwzględna większość głosów w obecności co najmniej połowy liczby członków kolegium r.i.o. Według oceny sądu administracyjnego momentem podjęcia rozstrzygnięcia nadzorczego przez r.i.o. jest data podjęcia uchwały przez kolegium r.i.o. na przewidzianym powyższą ustawą posiedzeniu jawnym z zachowaniem obligatoryjnego czynnego udziału stron ${ }^{33}$. W posiedzeniu kolegium r.i.o. ma prawo uczestniczyć przedstawiciel podmiotu objętego nadzorem r.i.o., którego sprawa jest rozpatrywana. Przedstawiciel tego podmiotu powinien być powiadomiony o posiedzeniu kolegium ri.o. w celu umożliwienia mu udziału w postępowaniu i przedstawienia swojego stanowiska ${ }^{34}$. Przepis art. 18 ust. 3 ustawy o r.i.o. nie zawiera jednak unormowań określających, w jakim trybie takie zawiadomienie powinno nastąpić. Wybrany przez r.i.o. sposób zawiadomienia musi gwarantować stronie czynny udział w postępowaniu ${ }^{35}$. Uznano, że publikowanie z tygodniowym wyprzedzeniem zawiadomień o posiedzeniach kolegium r.i.o. oraz rozpatrywanych na nich uchwałach i zarządzeniach w drodze elektronicznej na

33 Wyrok NSA z dnia 22 lipca 2014 r., II GSK 818/13, LEX nr 1519208.

34 Wyrok WSA w Gdańsku z dnia 19 października 2016 r., I SA/Gd 952/16, Legalis nr 1541086.

35 Wyrok WSA w Gdańsku z dnia 9 kwietnia 2014 r., I SA/Gd 167/14, Legalis nr 953225. 
stronie internetowej Biuletynu Informacji Publicznej r.i.o. jest sposobem gwarantującym stronie czynny udział w postępowaniu ${ }^{36}$.

Uchwała kolegium ri.i.o. jest również formą działania tego organu w przypadku przyjmowania raportów o stanie gospodarki finansowej j.s.t. oraz związków j.s.t. Zgodnie $\mathrm{z}$ art. 10a ustawy o r.i.o. ww. raporty są sporządzane na podstawie wyników działalności nadzorczej, kontrolnej i opiniodawczej, w razie potrzeby wskazania organom j.s.t. lub związków j.s.t. powtarzających się nieprawidłowości lub zagrożenia niewykonania ustawowych zadań. Można stwierdzić, że zadanie polegające na przygotowywaniu ww. raportów wskazuje na dualny charakter działań r.i.o., ponieważ obok nadzoru formalnoprawnego pojawiają się również elementy nadzoru ekonomicznego ${ }^{37}$. Decyzję o potrzebie sporządzenia raportu podejmuje kolegium r.i.o. i wyłącznie do tego organu należy ocena przesłanek uzasadniających podjęcie tej decyzji ${ }^{38}$. Z cytowanego przepisu ustawy jednoznacznie wynika, że jest to wyłączna kompetencja kolegium r.i.o., a więc nie jest możliwe sporządzenie takiego raportu na wniosek organu stanowiącego lub wykonawczego j.s.t. albo grupy radnych, ani też na wniosek innych organów administracji ${ }^{39}$.

Kolegium r.i.o. uchwałą decyduje o sporządzeniu raportu, określa jego zakres i termin oraz wyznacza członka kolegium r.i.o. odpowiedzialnego za przygotowanie projektu raportu. Po przyjęciu raportu przez kolegium r.i.o. prezes r.i.o. przekazuje raport organom: stanowiącemu i wykonawczemu właściwej j.s.t. lub związku j.s.t. Jeżeli raport dotyczy stanu gospodarki finansowej związku j.s.t., to należy go przekazać także organom j.s.t. należącym do tego związku. Organy j.s.t. lub związku j.s.t. mogą wnieść do kolegium r.i.o. zastrzeżenia do raportu w terminie 30 dni od dnia jego otrzymania. Kolegium r.i.o. w odrębnej uchwale oddala zastrzeżenia lub je uwzględnia i zmienia raport.

Stosownie do postanowień art. 19 cytowanej ustawy w r.i.o. funkcjonują składy orzekające złożone z trzech członków kolegium r.i.o., do ich właściwości należy wydawanie opinii w sprawach określonych w ustawach. Opinie są wydawane w formie uchwał składów orzekających. Jeżeli opinia dotyczy wniosku komisji rewizyjnej organu stanowiącego j.s.t. w sprawie absolutorium lub uchwały rady gminy o nieudzieleniu wójtowi (burmistrzowi, prezydentowi miasta) absolutorium, to powinna być wydana w terminie 14 dni. Od uchwał składów orzekających przysługuje odwołanie do kolegium r.i.o. w terminie 14 dni od dnia doręczenia uchwały. Nie później niż w terminie 14 dni od daty wniesienia kolegium r.i.o.

36 Wyrok WSA w Gdańsku z dnia 15 października 2009 r., I SA/Gd 611/09, Legalis nr 223162.

37 P. Kowalski, Regionalne izby obrachunkowe jako organ nadzoru formalnoprawnego czy organ nadzoru ekonomicznego?, „Finanse Komunalne” 2015, nr 3, s. 61-67.

38 K. Sawicka, Rola regionalnych izb obrachunkowych w procesie sanacji finansów lokalnych - wybrane zagadnienia, [w:] Sanacja finansów publicznych w Polsce. Aspekty prawne i ekonomiczne, red. K. Święch, A. Zalcewicz, Szczecin 2005, s. 496.

39 P. Grzegorzewski, Regionalne izby obrachunkowe w świetle nowelizacji ustawy o regionalnych izbach obrachunkowych z 24 lipca 2003 roku, „Finanse Komunalne” 2004, nr 3, s. 7. 
obowiązane jest rozpatrzeć odwołanie od: opinii wydanej przez skład orzekający w sprawach o przedłożonym projekcie uchwały budżetowej j.s.t.; przedłożonej przez organ wykonawczy j.s.t. informacji o przebiegu wykonania budżetu za pierwsze półrocze; przedłożonego przez organ wykonawczy j.s.t. sprawozdania $\mathrm{z}$ wykonania budżetu wraz z informacją o stanie mienia j.s.t. Według art. $25 \mathrm{~b}$ ust. 3 ustawy o r.i.o. uchwały kolegium r.i.o. w sprawach odwoławczych zapadają zwykłą większością głosów, na posiedzeniu niejawnym.

Według stanowiska sądów administracyjnych uchwała r.i.o. w przedmiocie rozpatrzenia odwołania od opinii wyrażonej w uchwale składu orzekającego tej izby, wydana na podstawie art. 20 ust. 1 ustawy o r.i.o. nie jest formą działania administracji publicznej, o jakiej mowa w art. $3 \S 2$ pkt 4 Ustawy z dnia 30 sierpnia 2002 roku - Prawo o postępowaniu przed sądami administracyjnymi ${ }^{40}$, tzn. nie jest innym aktem lub inną czynnością z zakresu administracji publicznej dotyczącą uprawnień lub obowiązków wynikających z przepisów prawa ${ }^{41}$. Uchwały podejmowane na podstawie art. 20 ust. 1 ustawy o r.i.o. nie podlegają zaskarżeniu do sądu administracyjnego, ponieważ nie są one aktami nadzoru nad działalnością organów j.s.t. Ich treścią są opinie, czyli formy współdziałania, które merytorycznie nie wiążą tych organów ${ }^{42}$.

\section{Podsumowanie}

Wraz ze zmianami w przedmiotowym zakresie działalności prowadzonej przez r.i.o. odpowiednio zmieniał się zakres uprawnień i obowiązków kolegium r.i.o. oraz jego przewodniczącego, tzn. prezesa r.i.o. $Z$ jednej strony następowało poszerzanie tego zakresu, natomiast $\mathrm{z}$ drugiej zauważalna jest coraz większa specjalizacja odnosząca się do oceny gospodarowania zasobami finansowymi w samorządzie terytorialnym. Zadania te są realizowane za pomocą różnych instrumentów (nadzorczych, kontrolnych lub niewładczych) na etapie planowania, gromadzenia i wydatkowania środków publicznych, ewidencjonowania operacji finansowych oraz sprawozdawczości ${ }^{43}$. Pozytywnie zweryfikowano hipotezę o rosnącej roli r.i.o., wraz z kolejnymi nowelizacjami ustawy o r.i.o., jako wyspecjalizowanego podmiotu w sferze kontroli gospodarki finansowej oraz nadzoru nad działalnością finansową j.s.t. i innych jednostek organizacyjnych sektora sa-

40 Dz.U. z 2018 r. poz. 1302 ze zm.

41 Postanowienie NSA z dnia 4 listopada 2016 r., II GSK 4909/16, ONSAiWSA 2017, nr 6, poz. 99.

42 Postanowienie WSA w Gliwicach z dnia 23 września 2013 r., I SA/GI 1193/13, OwSS 2015, nr 4, s. 112.

43 T. Dobek, Działania regionalnych izb obrachunkowych w zakresie oceny komunalnej gospodarki finansowej, „Finanse Komunalne” 2010, nr 1-2, s. 118. 
morządu terytorialnego. Ilościowy wzrost zadań r.i.o. oraz coraz bardziej złożony charakter gospodarki finansowej j.s.t. i innych podmiotów sektora samorządu terytorialnego wymaga nie tylko systematycznego poszerzania składu kolegium r.i.o., ale również stałego podnoszenia poziomu wymagań adresowanych do kandydatów przewidzianych do objęcia funkcji w tym organie kolegialnym, który od dnia 1 lipca 2005 roku jest jedynym organem ri.o.

Jednak nie wszystkie zadania określone w ustawie o r.i.o. kolegium r.i.o. wykonuje bezpośrednio i w pełnym składzie osobowym. Szczególnym przypadkiem, ograniczonym tylko do wydawania opinii w sprawach ściśle określonych przez ustawodawcę, jest działalność składów orzekających złożonych z trzech członków kolegium r.i.o. Wprowadzono kontrolę, sprawowaną przez kolegium r.i.o., w odniesieniu do ww. uchwał składów orzekających. W tym zakresie w art. 20 ust. 1 ustawy o r.i.o. użyto stwierdzenia „od uchwał składów orzekających służy odwołanie do kolegium izby". Składy orzekające nie są organami r.i.o., o czym wprost przesądza art. 14 ustawy o r.i.o., w którym wymieniono tylko jeden organ r.i.o., tzn. kolegium r.i.o. W doktrynie wskazuje się, że składy orzekające nie są organami administracji publicznej, lecz jedynie wewnętrznymi organami kolegium r.i.o. ${ }^{44}$ Zastosowanie trybu odwoławczego od uchwał podejmowanych przez składy orzekające wyłaniane z kolegium r.i.o. mogłoby sugerować, że ustawodawca zamierzał nadać im cechy organu oraz wprowadzić dwuinstancyjne postępowanie wewnątrz tej samej struktury organizacyjnej, jaką jest r.i.o. Rozwiązanie takie należy ocenić krytycznie, ponieważ w pełnym składzie kolegium r.i.o. rozpatrującym odwołanie od uchwały składu orzekającego znajdują się również członkowie tego kolegium, którzy w ramach składu orzekającego podejmowali uchwałę zaskarżaną w trybie odwoławczym. Strona wnosząca odwołanie zasadnie powinna oczekiwać obiektywnego działania kolegium r.i.o. jako organu odwoławczego.

Konkludując, w wyniku ewolucji rozwiązań normatywnych ukształtowano status prawny kolegium r.i.o. jako organu podmiotu wyspecjalizowanego w wykonywaniu funkcji kontrolnych, nadzorczych oraz pozostałych o wyraźnie zaznaczonych granicach przedmiotowych i podmiotowych. Ewolucja przebiegała w sposób wyważony, o czym decydowało umocowanie r.i.o. bezpośrednio w Konstytucji Rzeczypospolitej Polskiej z dnia 2 kwietnia 1997 roku. Ustrojodawca w art. 171 ust. 1 wprost określił r.i.o. jako organy nadzoru nad działalnością j.s.t. w zakresie spraw finansowych. Ustawodawca rozszerzył podmiotowe granice tej działalności na związki j.s.t., stowarzyszenia j.s.t. oraz inne podmioty sektora samorządu terytorialnego, ale nie naruszył głównej koncepcji polskiego ustrojodawcy. Nie można jednak uznać procesu ewolucji rozwiązań prawnych regulujących pozycję

44 P. Ciszewski, Komentarz do art. 19, [w:] Regionalne izby obrachunkowe. Charakterystyka ustrojowa i komentarz do ustawy, red. M. Stec, Warszawa 2010, s. 548. 
prawną r.i.o. i jej kolegium za zakończony. Dyskusje o pozycji ustrojowej r.i.o. ${ }^{45}$ oraz propozycje ustawodawcze dowodzą, że nadal istnieje potrzeba dokonania rewizji dotychczasowych rozwiązań prawnych ${ }^{46}$.

\section{Bibliografia}

Badurowicz K., Drab T., Status ustrojowy regionalnych izb obrachunkowych i ich wplyw na procedurę budżetowa jednostek samorządu terytorialnego, „Rocznik Samorządowy” 2016, t. 5.

Bouvier M., Finanse lokalne we Francji, Warszawa 1999.

Ciszewski P., Komentarz do art. 19, [w:] Regionalne izby obrachunkowe. Charakterystyka ustrojowa i komentarz do ustawy, red. M. Stec, Warszawa 2010.

Cybulski B., Od Głównej Izby Obrachunkowej Księstwa Warszawskiego do regionalnych izb obrachunkowych, [w:] Samorzad - finanse - nadzór i kontrola. XX-lecie regionalnych izb obrachunkowych, red. R.P. Krawczyk, M. Stec, Warszawa 2013.

Dobek T., Działania regionalnych izb obrachunkowych w zakresie oceny komunalnej gospodarki finansowej, „Finanse Komunalne” 2010, nr 1-2.

Etel L., O potrzebie zmian w lokalnym prawie podatkowym - cz. 1, „Finanse Komunalne” 2011, nr 11.

Gajl N., Cour des Comptes, Izba Obrachunkowa i Izby Regionalne we Francji, „Samorząd Terytorialny" $1992, \mathrm{nr} 4$.

Gajl N., Izba Obrachunkowa i regionalne izby obrachunkowe we Francji, „Kontrola Państwowa” 1992, nr 3.

Grzegorzewski P., Regionalne izby obrachunkowe w świetle nowelizacji ustawy o regionalnych izbach obrachunkowych z 24 lipca 2003 roku, „Finanse Komunalne” 2004, nr 3.

Kościelniak G., Najwyższa Izba Kontroli - 90 lat tradycji naczelnego organu kontroli państwowej. Współczesny obraz i proponowane kierunki zmian, „Państwo i Społeczeństwo” 2009, nr 3.

45 Zgłaszane są postulaty dokonania zmian ustawodawstwa w zakresie zwiększenia uprawnień nadzorczych i kontrolnych r.i.o. Proponuje się m.in. wprowadzenie ustawowego obowiązku przedkładania r.i.o. projektów uchwał podatkowych razem z uzasadnieniem zawierającym oszacowanie skutków finansowych, czy upoważnienie r.i.o. - na zasadach analogicznych do przyjętych dla wojewody w art. 96 ust. 2 ustawy o samorządzie gminnym - do wzywania wójta do zaprzestania naruszeń prawa, np. w przypadku stwierdzenia niedotrzymania przez niego terminu przekazania uchwał rady gminy do r.i.o., L. Etel, O potrzebie zmian $w$ lokalnym prawie podatkowym - cz. 1, „Finanse Komunalne” 2011, nr 11, s. 15.

46 Ustawą z dnia 8 czerwca 2017 r. o zmianie ustawy o regionalnych izbach obrachunkowych oraz niektórych innych ustaw planowano wzmocnić kontrolne i pomocnicze funkcje ri.o. wobec samorządu terytorialnego oraz zwiększyć skuteczność działań nadzorczych i kontrolnych w przypadku nadmiernego zadłużenia się j.s.t. Prezydent RP odmówił podpisania ustawy i zwrócił się do Sejmu o ponowne jej rozpatrzenie, zgłaszając zastrzeżenia m.in. do rozwiązań wprowadzających zniesienie procedury konkursowej przy wyłanianiu prezesów i członków kolegiów r.i.o., przyznających Prezesowi Rady Ministrów swobodę powoływania i odwoływania prezesów izb i za ich pośrednictwem pozostałych członków kolegiów, eliminujących instytucję pozaetatowych członków kolegium izb oraz znoszących zasadę parytetu samorządu terytorialnego w wyłanianiu członków kolegium izby. 
Kowalski P., Regionalne izby obrachunkowe jako organ nadzoru formalnoprawnego czy organ nadzoru ekonomicznego?, „Finanse Komunalne” 2015, nr 3.

Krawczyk R.P., Funkcja kontrolna regionalnych izb obrachunkowych - aktualne dylematy, „Finanse Komunalne" 2013, nr 1-2.

Kwiatkowska M., Geneza i przesłanki powstania regionalnych izb obrachunkowych w Polsce, „Prace Naukowe Wałbrzyskiej Wyższej Szkoły Zarzadzania i Przedsiębiorczości” 2013, nr 4.

Pilarczyk P.M., Kontrola państwowa w Polsce przedrozbiorowej, „Kontrola Państwowa” 2016, nr 2.

Ruśkowski E., Tegler E., Kontrola działalności finansowej gmin we Francji i w Niemczech — wnioski dla Polski, Białystok 1991.

Sawicka K., Pozycja ustrojowa regionalnych izb obrachunkowych w Polsce, [w:] Regulacje prawno-podatkowe i rozwiazania finansowe. Księa jubileuszowa Profesora Jana Głuchowskiego, Torun 2002.

Sawicka K., Rola regionalnych izb obrachunkowych w procesie sanacji finansów lokalnych — wybrane zagadnienia, [w:] Sanacja finansów publicznych w Polsce. Aspekty prawne i ekonomiczne, red. K. Święch, A. Zalcewicz, Szczecin 2005.

Skąpski M., Swora M., Prawne problemy organizacji regionalnych izb obrachunkowych, „Ruch Prawniczy, Ekonomiczny i Socjologiczny" 2004, nr 2.

Sylwestrzak A., Regionalne izby obrachunkowe w III Rzeczypospolitej Polskiej, „Gdańskie Studia Prawnicze" 2002, nr 8.

Sylwestrzak A., Regionalne izby obrachunkowe, [w:] Prawo - Administracja - Policja. Ksiega pamiatkowa Profesora Wincentego Bednarka, red. J. Dobkowski, Olsztyn 2006.

Dębowska-Romanowska T., O pojęciu ,, spraw finansowych” w rozumieniu art. 171 ust. 2 Konstytucji, „Gdańskie Studia Prawnicze” 2007, nr 1.

Turek T., Organy regionalnej izby obrachunkowej. Struktura organizacyjna, zadania i kompetencje, ,Miscellanea Iuridica” 2002, t. 2.

Turek T., Pozycja ustrojowa Prezesa Regionalnej Izby Obrachunkowej w strukturze organizacyjnej Izby, „Miscellanea Iuridica” 2007, t. 9.

Turek T., Regionalna izba obrachunkowa jako organ kontroli nad działalnościa jednostek samorządu terytorialnego w zakresie gospodarki finansowej, [w:] System finansów samorządu terytorialnego. Wybrane problemy, red. L. Patrzałek, Poznań-Wrocław 2003.

Turek T., Wewnętrzna struktura organizacyjna regionalnych izb obrachunkowych, „Gubernaculum et Administratio" 2004, nr 3.

Wilk J., O właściwości nadzorczej regionalnej izby obrachunkowej nad uchwałami organów jednostek samorzadu terytorialnego w sprawie podatków i opłat lokalnych, „Nowe Zeszyty Samorządowe" 2012, nr 1.

Zawadzka-Pąk U.K., Regionalne izby obrachunkowe we Francji, „Finanse Komunalne” 2010, nr 11.

\section{Evolution of the legal status of the Boards of Regional Accounting Chambers}

\section{Summary}

Regional Accounting Chambers, established in 1992 and operating since 1993, are a supervisory body that serve as a regulator of local government units with regard to financial matters. Over the 25-year period, the scope of the Chamber's duties and tasks has been continuously expanded. This fact has significantly affected the legal status of the Board of the Chamber, which is the only 
body managed by the Chairman of the Chamber. The legal status of the Board of the Chamber is defined by formal statutory requirements set for candidates aspiring to be members of the Board, the competition procedure in force and the fact that they are appointed by the Prime Minister at the request of the Chamber's Chairman. Members of the Chamber's Board enjoy legal protection as public officers when it comes to the tasks executed, though they are independent with regard to supervisory and control functions. The abovementioned statutory privileges should affect positively the judicial and consultative practice of the Boards of Regional Accounting Chambers.

Keywords: local government, regional accounting chamber, supervision, financial issues, opinions. 